Phosphorus Research Bulletin Vol. 22 (2008) pp. 17-21

\title{
OPTIMIZATION OF HYDROTHERMAL SYNTHESIS OF PLATE-LIKE HYDRATED CERIUM PHOSPHATES AND THEIR PHOTOCHEMICAL PROPERTIES
}

\author{
Tsugio Sato ${ }^{*}$, Chigusa Sato, Shu Yin \\ (*Corresponding author: tsusato@tagen.tohoku.ac.jp) \\ Institute of Multidisciplinary Research for Advanced Materials, Tohoku University, \\ 2-1-1 Ktahira, Aoba-ku, Sendai 980-8577, Japan
}

Keywords: Hydrated Cerium phosphate, Plate-like particle, Hydrothermal synthesis, UV-shielding, Photochemical Properties

Abstract: Plate-like hydrated cerium phosphate, $\mathrm{Ce}_{2}\left(\mathrm{PO}_{4}\right)_{2} \mathrm{HPO}_{4} \cdot \mathrm{H}_{2} \mathrm{O}$, has attracted attention because of its unique UV-shielding ability with excellent comfort when applied on the skin. Optimization of preparation conditions of hydrated cerium phosphate is required to obtain medium size plate-like particles of 5-50 $\mu \mathrm{m}$ in diameter which provide good comfort for human skin. Plate-like hydrated cerium phosphate, ca $20 \mu \mathrm{m}$ in diameter, was obtained by the hydrothermal reaction of $\mathrm{Ce}\left(\mathrm{SO}_{4}\right)_{2}$ in $\mathrm{H}_{3} \mathrm{PO}_{4}$ aqueous solution at $200^{\circ} \mathrm{C}$ for $3 \mathrm{~h}$. The sample showed excellent comfort, absorption ability of light less than $450 \mathrm{~nm}$ of wavelength and lower oxidation catalytic activity than undoped ceria.

(Received March 13, 2008; Accepted April 1, 2008)

\section{INTRODUCTION}

The damaging effects of UV rays have attracted attention and various UV-shielding materials have been developed in response. Nanopowders of titania $\left(\mathrm{TiO}_{2}\right)$, zinc oxide $(\mathrm{ZnO})$ and calcia-doped ceria $\left(\mathrm{Ce}_{1-\mathrm{x}} \mathrm{Ca}_{\mathrm{x}} \mathrm{O}_{2-\mathrm{x}}\right)$ have been commercially used as inorganic sunscreens in personal care products. ${ }^{1-7)}$ However, nanoparticles of inorganic materials are not comfortable and do not provide good coverage over the skin because of the agglomeration of the particles. The plate-like particles such as mica, talc, etc. are often used to improve the comfort and covering ability of inorganic UV shielding materials. The mixing with mica and talc, however, generally results in a decrease in the UV-shielding performance since mica and talc do not possess UV-absorption ability. In a previous paper $^{8)}$ we reported that the comfort of wearing calcia-doped ceria nanoparticles was successfully improved without loss of UV-shielding performance by using plate-like lepidocrocite type potassium lithium titanate, $\mathrm{K}_{0.8} \mathrm{Li}_{0.266} \mathrm{Ti}_{1.734} \mathrm{O}_{4}$, possessing the band gap energy of ca. $3.5 \mathrm{eV}$ and absorption ability of UV ray less than $350 \mathrm{~nm}$ of wavelength in stead of mica and talc. Upon coupling calcia-doped ceria nanoparticles with plate-like materials, two advantages can be expected. First, a softer and nicer feeling upon application will be acquired for calcia-doped ceria nanoparticles. Second, better distribution with improved coverage ability of calcia-doped ceria nanoparticles on the skin, will inevitably enhance the UV-shielding ability of $\mathrm{CaO}$-doped ceria. From the point of view of UV-shielding, the plate-like particles are required to show absorption ability of UV-ray less than $400 \mathrm{~nm}$. Hydrated cerium phosphate possessing band gap energy ca. $2.7 \mathrm{eV}^{9)}$ seems to be a candidate material to be used instead of titanate possessing larger band gap energy, ca. $3.5 \mathrm{eV}$. Therefore, in the present study we investigated the optimization of preparation conditions of plate-like hydrated cerium phosphate by the hydrothermal reaction and the photochemical properties of the product were evaluated.

\section{MATERIALS AND METHODS}

Hydrothermal synthesis of cerium phosphates: After placing $5 \mathrm{mmol}$ of $\mathrm{Ce}\left(\mathrm{SO}_{4}\right)_{2} \cdot 4 \mathrm{H}_{2} \mathrm{O}$ powder and desired amounts of 1-5 $\mathrm{M} \mathrm{H}_{3} \mathrm{PO}_{4}$ aqueous solution with the $\mathrm{P} / \mathrm{Ce}$ atomic ratio of $2.5-5.0$ in an Teflon-lined autoclave with a capacity of $20 \mathrm{~cm}^{3}$, the autoclave was sealed, placed in an electric furnace or a microwave oven (Berghof, MWS-2) and heated at different temperatures for desired times. After cooling the autoclave in air, the precipitate was filtered, washed with distilled water, and vacuum dried at $60^{\circ} \mathrm{C}$ for $12 \mathrm{~h}$.

The morphology of the particles was observed using a scanning electron microscope (Hitachi, S-4100L). The crystallographic phase constitution was characterized by X-ray diffraction (XRD) analysis using graphite monochromatized $\mathrm{CuK} \alpha$ radiation (Shimadzu, XD-01). The UV-shielding abilities of samples were evaluated by measuring the transmittance spectra of thin films uniformly dispersing sample powders with an UV-Vis spectrophotometer (SHIMADZU, UV-2450), where 2 $\mathrm{g}$ of the sample, $4 \mathrm{~g}$ of nitrocellulose of industrial 
grade, $10 \mathrm{~g}$ of ethyl acetate and $9 \mathrm{~g}$ of butyl acetate were mixed uniformly using a paint shaker and $100 \mathrm{~g}$ zirconia ball, $2.7 \mathrm{~mm}$ in diameter for $40 \mathrm{~h}$. The dispersion mixture was applied onto a quartz glass plate with an applicator. The thickness of the film was $12.5 \mu \mathrm{m}$. The catalytic activity for the oxidation of organic material was determined using a conductometric determination method (Rancimat system, Metrohm E679) ${ }^{10}$. One gram of the sample powder was mixed with $10 \mathrm{~g}$ of castor oil and heated to $120^{\circ} \mathrm{C}$ while bubbling air at $0.5 \mathrm{dm}^{3} \cdot \mathrm{min}^{-1}$, where the air was introduced into distilled water attached to an electric conductivity measurement cell. The catalytic activity was evaluated by measuring the increase in the conductivity of distilled water resulting from trapping of volatile molecules formed by the oxidation of castor oil on heating. The feeling of wearing the sample powder on the skin was evaluated using a friction tester (Katotech, KES-SE) which employs a piano wire as a friction element and artificial leather (Idemitsu Technofine Co., Sapurare ()), where the sample powder was applied on the artificial leather using a make-up brush.

\section{RESULTS AND DISCUSSION}

X-ray diffraction patterns of the samples prepared by the microwave assisted hydrothermal reaction and normal hydrothermal reaction under various conditions are shown in FIGURES 1 and 2. Two different diffraction patterns which could be identified as $\mathrm{Ce}\left(\mathrm{PO}_{4}\right)_{1.5}\left(\mathrm{H}_{2} \mathrm{O}\right)_{0.5}\left(\mathrm{H}_{3} \mathrm{O}\right)_{0.5}\left(\mathrm{H}_{2} \mathrm{O}\right)_{0.5}$ with the monoclinic symmetry of the space group $\mathrm{C} 2 / \mathrm{c}$ and $\mathrm{Ce}_{2}\left(\mathrm{PO}_{4}\right)_{2} \mathrm{HPO}_{4} \cdot \mathrm{H}_{2} \mathrm{O}$ with the monoclinic symmetry of the space group $\mathrm{C} 2 / \mathrm{c}^{11}$, were observed for the samples prepared by the microwave assisted hydrothermal reaction. It seemed that $\mathrm{Ce}\left(\mathrm{PO}_{4}\right)_{1.5}\left(\mathrm{H}_{2} \mathrm{O}\right)_{0.5}\left(\mathrm{H}_{3} \mathrm{O}\right)_{0.5}\left(\mathrm{H}_{2} \mathrm{O}\right)_{0.5}$ is formed at lower temperature and lower $\mathrm{P} / \mathrm{Ce}$ atomic ratio. In contrast, only $\mathrm{Ce}_{2}\left(\mathrm{PO}_{4}\right)_{2} \mathrm{HPO}_{4} \cdot \mathrm{H}_{2} \mathrm{O}$ was formed by the normal hydrothermal reaction even such low temperature and $\mathrm{P} / \mathrm{Ce}$ atomic ratio as $150^{\circ} \mathrm{C}$ and 2.5. Since $\mathrm{Ce}\left(\mathrm{PO}_{4}\right)_{1.5}\left(\mathrm{H}_{2} \mathrm{O}\right)_{0.5}\left(\mathrm{H}_{3} \mathrm{O}\right)_{0.5}\left(\mathrm{H}_{2} \mathrm{O}\right)_{0.5}$ was formed only by the microwave assisted hydrothermal reaction, $\mathrm{Ce}\left(\mathrm{PO}_{4}\right)_{1.5}\left(\mathrm{H}_{2} \mathrm{O}\right)_{0.5}\left(\mathrm{H}_{3} \mathrm{O}\right)_{0.5}\left(\mathrm{H}_{2} \mathrm{O}\right)_{0.5}$ seems to be an unstable intermediate compound and is formed only when the heating rate is fast.

Scanning electron micrographs of the samples prepared by the microwave assisted hydrothermal reaction under various conditions are shown in FIGURES 3, where the samples (a) and (b) consisted of $\mathrm{Ce}\left(\mathrm{PO}_{4}\right)_{1.5}\left(\mathrm{H}_{2} \mathrm{O}\right)_{0.5}\left(\mathrm{H}_{3} \mathrm{O}\right)_{0.5}\left(\mathrm{H}_{2} \mathrm{O}\right)_{0.5}$, on the other hand, samples (c) and (d) consisted of $\mathrm{Ce}_{2}\left(\mathrm{PO}_{4}\right)_{2} \mathrm{HPO}_{4} \cdot \mathrm{H}_{2} \mathrm{O}$. It is seen that samples (a) and (b) consisted of rod-like particles, ca. 3-5 $\mu \mathrm{m}$ in length and $0.1 \mu \mathrm{m}$ in diameter, and samples (c) and (d) consisted of plate-like particles, ca. 3-5 $\mu \mathrm{m}$ in diameter. The change in the morphology of the

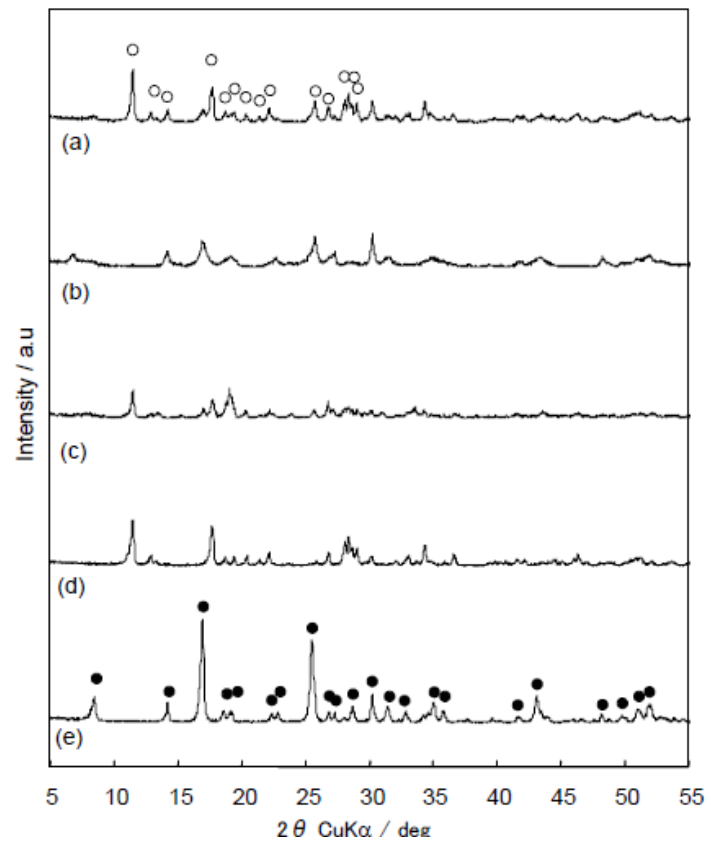

FIGURE 1 X-ray diffraction patterns of the samples prepared by the microwave assisted hydrothermal reactions under various conditions. (a) $1.0 \mathrm{M} \mathrm{H}_{3} \mathrm{PO}_{4}, \mathrm{P} / \mathrm{Ce}=2.5,150^{\circ} \mathrm{C}, 3 \mathrm{~h}$, (b) $1.0 \mathrm{M}$ $\mathrm{H}_{3} \mathrm{PO}_{4}, \mathrm{P} / \mathrm{Ce}=5.0,150^{\circ} \mathrm{C}, 3 \mathrm{~h}$, (c) $1.0 \mathrm{M} \mathrm{H}_{3} \mathrm{PO}_{4}$, $\mathrm{P} / \mathrm{Ce}=2.5,200^{\circ} \mathrm{C}, 3 \mathrm{~h}$, (d) $2.5 \mathrm{M} \mathrm{H}_{3} \mathrm{PO}_{4}, \mathrm{P} / \mathrm{Ce}=2.5$, $200^{\circ} \mathrm{C}, 3 \mathrm{~h}$, (e) $2.5 \mathrm{M} \mathrm{H}_{3} \mathrm{PO}_{4}, \mathrm{P} / \mathrm{Ce}=5.0,200^{\circ} \mathrm{C}, 3 \mathrm{~h}$.

$\mathrm{O} \mathrm{Ce}\left(\mathrm{PO}_{4}\right)_{1.5}\left(\mathrm{H}_{2} \mathrm{O}\right)_{0.5}\left(\mathrm{H}_{3} \mathrm{O}\right)_{0.5}\left(\mathrm{H}_{2} \mathrm{O}\right)_{0.5}$

- $\mathrm{Ce}_{2}\left(\mathrm{PO}_{4}\right)_{2} \mathrm{HPO}_{4} \cdot \mathrm{H}_{2} \mathrm{O}$

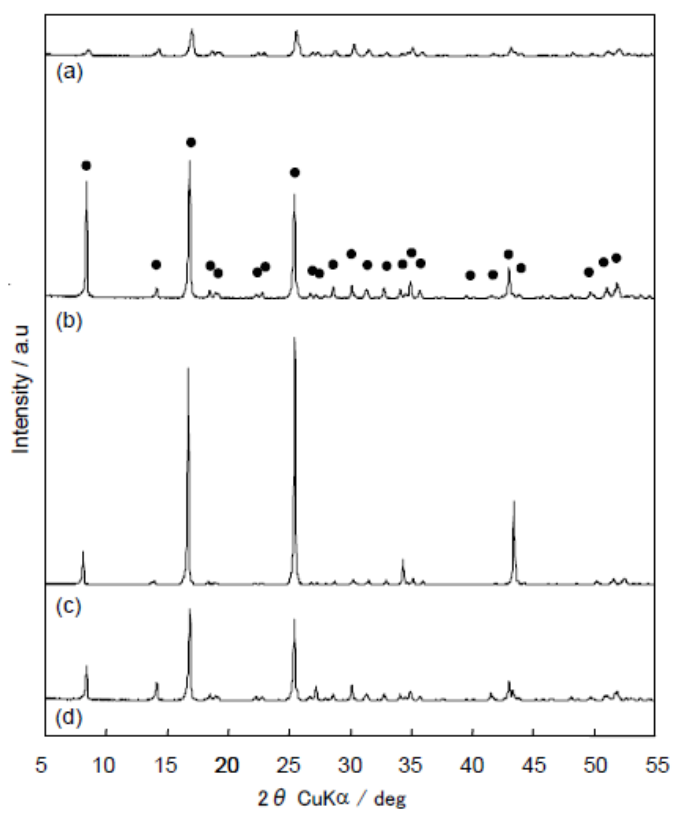

FIGURE 2 X-ray diffraction patterns of the samples prepared by the normal hydrothermal reactions under various conditions. (a) $2.5 \mathrm{M}$ $\mathrm{H}_{3} \mathrm{PO}_{4}, \mathrm{P} / \mathrm{Ce}=2.5,150^{\circ} \mathrm{C}, 1.5 \mathrm{~h}$, (b) $2.5 \mathrm{M} \mathrm{H}_{3} \mathrm{PO}_{4}$, $\mathrm{P} / \mathrm{Ce}=2.5,150^{\circ} \mathrm{C}, 7 \mathrm{~d}$, (c) $1.0 \mathrm{M} \mathrm{H}_{3} \mathrm{PO}_{4}, \mathrm{P} / \mathrm{Ce}=2.5$, $200^{\circ} \mathrm{C}, 3 \mathrm{~h}$, (d) $2.5 \mathrm{M} \mathrm{H}_{3} \mathrm{PO}_{4}, \mathrm{P} / \mathrm{Ce}=2.5,200^{\circ} \mathrm{C}, 3 \mathrm{~h}$.

๑: $\mathrm{Ce}_{2}\left(\mathrm{PO}_{4}\right)_{2} \mathrm{HPO}_{4} \cdot \mathrm{H}_{2} \mathrm{O}$ 

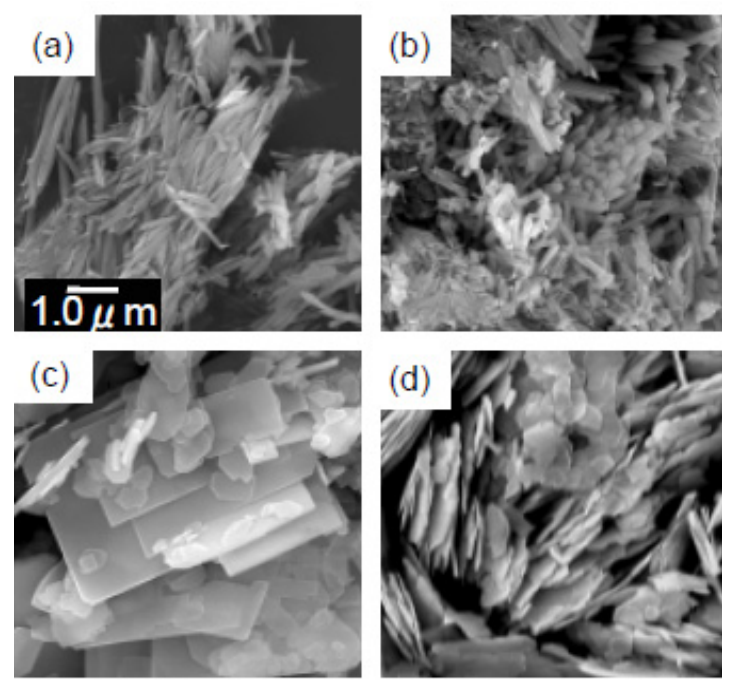

FIGURE 3 SEM images of the samples prepared by the microwave assisted hydrothermal reactions under various conditions. (a) $1.0 \quad \mathrm{M} \quad \mathrm{H}_{3} \mathrm{PO}_{4}$, $\mathrm{P} / \mathrm{Ce}=2.5,150^{\circ} \mathrm{C}, 1.5 \mathrm{~h}$, (b) $1.0 \mathrm{M} \mathrm{H}_{3} \mathrm{PO}_{4}, \mathrm{P} / \mathrm{Ce}=2.5$, $150^{\circ} \mathrm{C}, 3 \mathrm{~h}$, (c) $1.25 \mathrm{M} \mathrm{H}_{3} \mathrm{PO}_{4}, \mathrm{P} / \mathrm{Ce}=2.5,200^{\circ} \mathrm{C}, 3 \mathrm{~h}$, (d) $2.5 \mathrm{M} \mathrm{H}_{3} \mathrm{PO}_{4}, \mathrm{P} / \mathrm{Ce}=5.0,200^{\circ} \mathrm{C}, 3 \mathrm{~h}$.

particle seems to be related with the crystal structure. The perspective view of the crystal structure of $\mathrm{Ce}\left(\mathrm{PO}_{4}\right)_{1.5}\left(\mathrm{H}_{2} \mathrm{O}\right)_{0.5}\left(\mathrm{H}_{3} \mathrm{O}\right)_{0.5}\left(\mathrm{H}_{2} \mathrm{O}\right)_{0.5}$ and that of $\mathrm{Ce}_{2}\left(\mathrm{PO}_{4}\right)_{2} \mathrm{HPO}_{4} \cdot \mathrm{H}_{2} \mathrm{O}$ were reported as shown in FIGURE 4 (a) and (b) ${ }^{11}$. Namely, it was found that $\mathrm{Ce}\left(\mathrm{PO}_{4}\right)_{1.5}\left(\mathrm{H}_{2} \mathrm{O}\right)_{0.5}\left(\mathrm{H}_{3} \mathrm{O}\right)_{0.5}\left(\mathrm{H}_{2} \mathrm{O}\right)_{0.5}$ possessing a tunnel structure tends to grow as one dimensional rod-like particle, in contrast, $\mathrm{Ce}_{2}\left(\mathrm{PO}_{4}\right)_{2} \mathrm{HPO}_{4} \cdot \mathrm{H}_{2} \mathrm{O}$ possessing a layered structure tends to grow as two

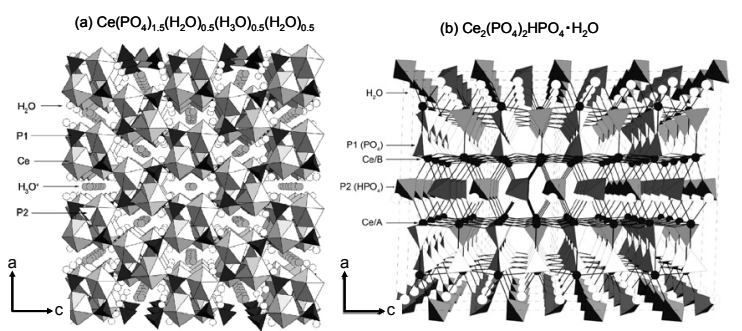

FIGURE 4 Perspective views of the crystal structures of (a) $\mathrm{Ce}\left(\mathrm{PO}_{4}\right)_{1.5}\left(\mathrm{H}_{2} \mathrm{O}\right)_{0.5}\left(\mathrm{H}_{3} \mathrm{O}\right)_{0.5}\left(\mathrm{H}_{2} \mathrm{O}\right)_{0.5}$ and (b) $\mathrm{Ce}_{2}\left(\mathrm{PO}_{4}\right)_{2} \mathrm{HPO}_{4} \cdot \mathrm{H}_{2} \mathrm{O}$

dimensional plate-like particle.

Scanning electron micrographs of the samples prepared by the normal hydrothermal reaction under various conditions are shown in FIGURES 5, where all samples were identified as single phase $\mathrm{Ce}_{2}\left(\mathrm{PO}_{4}\right)_{2} \mathrm{HPO}_{4} \cdot \mathrm{H}_{2} \mathrm{O}$. All $\mathrm{Ce}_{2}\left(\mathrm{PO}_{4}\right)_{2} \mathrm{HPO}_{4} \cdot \mathrm{H}_{2} \mathrm{O}$ samples consisted of plate-like structure. Particle size increased with increasing temperature, $\mathrm{H}_{3} \mathrm{PO}_{4}$ concentration and reaction time. In the previous papers $^{9,13}$ it took long time such as1-4 weeks to
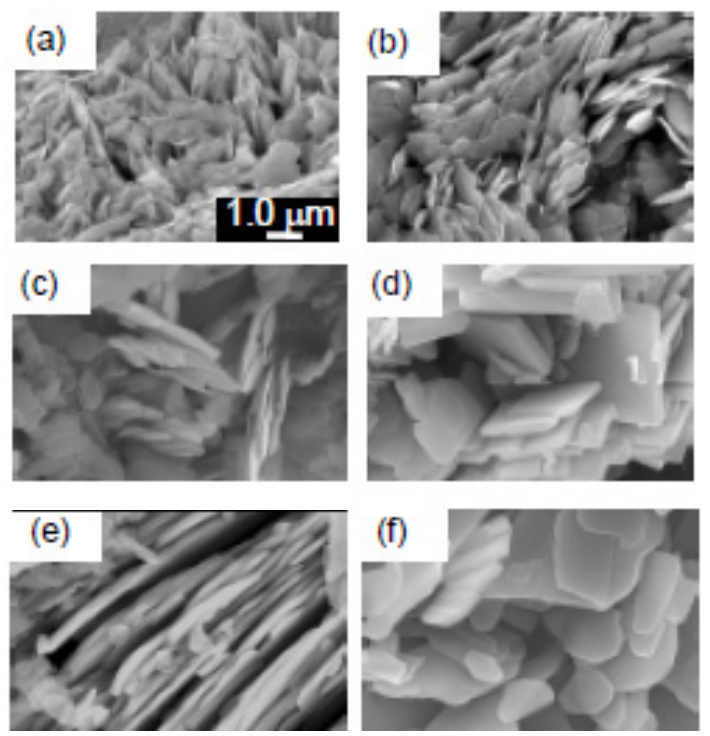

FIGURE 5 SEM images of the samples prepared by the normal hydrothermal reactions under various conditions. (a) $5.0 \mathrm{M} \mathrm{H}_{3} \mathrm{PO}_{4}, \mathrm{P} / \mathrm{Ce}=2.5,150^{\circ} \mathrm{C}, 3 \mathrm{~h}$, (b) $5.0 \mathrm{M} \mathrm{H}_{3} \mathrm{PO}_{4}, \mathrm{P} / \mathrm{Ce}=3.0,150^{\circ} \mathrm{C}, 3 \mathrm{~h}$, (c) $2.5 \mathrm{M}$ $\mathrm{H}_{3} \mathrm{PO}_{4}, \mathrm{P} / \mathrm{Ce}=2.5,150^{\circ} \mathrm{C}, 7 \mathrm{~d}$, (d) $1.25 \mathrm{M} \mathrm{H}_{3} \mathrm{PO}_{4}$, $\mathrm{P} / \mathrm{Ce}=2.5,200^{\circ} \mathrm{C}, 3 \mathrm{~h}$, (e) $2.5 \mathrm{M} \mathrm{H}_{3} \mathrm{PO}_{4}, \mathrm{P} / \mathrm{Ce}=2.5$, $200^{\circ} \mathrm{C}, 3 \mathrm{~h}$, (f) $2.5 \mathrm{M} \mathrm{H}_{3} \mathrm{PO}_{4}, \mathrm{P} / \mathrm{Ce}=2.5,200^{\circ} \mathrm{C}, 72 \mathrm{~h}$.

prepare micro meter sized platelet particles of $\mathrm{Ce}_{2}\left(\mathrm{PO}_{4}\right)_{2} \mathrm{HPO}_{4} \cdot \mathrm{H}_{2} \mathrm{O}$. Therefore, it is notable that well dispersed micro meter sized plate-like particles, ca. 5-10 $\mu \mathrm{m}$ in diameter could be formed in such short reaction time as $3 \mathrm{~h}$ at $200^{\circ} \mathrm{C}$. It is great advantage for the practical application.

Transmittance spectra of the thin film of $\mathrm{Ce}_{2}\left(\mathrm{PO}_{4}\right)_{2} \mathrm{HPO}_{4} \cdot \mathrm{H}_{2} \mathrm{O}$ synthesized at $200^{\circ} \mathrm{C}$ for $3 \mathrm{~h}$ in $2.5 \mathrm{M} \mathrm{H}_{3} \mathrm{PO}_{4}$ with $\mathrm{P} / \mathrm{Ce}$ atomic ratio of (a) 2.5 by the normal hydrothermal reaction and (b) 5.0 by microwave assisted hydrothermal reaction together with those of (c) plate-like $\mathrm{K}_{0.8} \mathrm{Li}_{0.27} \mathrm{Ti}_{1.73} \mathrm{O}_{4}$ prepared

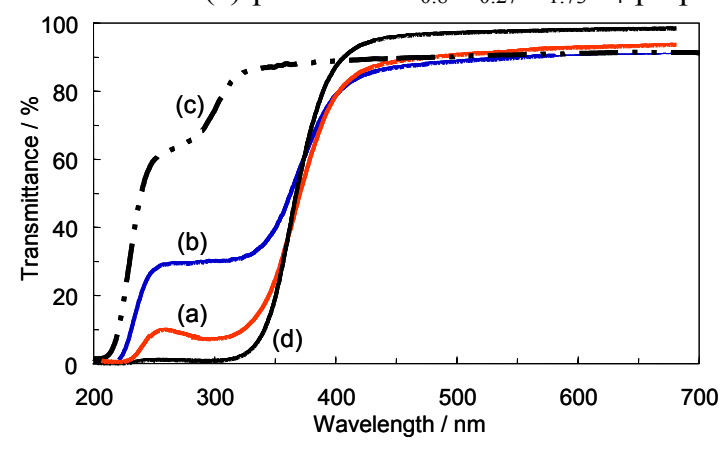

FIGURE 6 Transmittance spectra of the thin film of $\mathrm{Ce}_{2}\left(\mathrm{PO}_{4}\right)_{2} \mathrm{HPO}_{4} \cdot \mathrm{H}_{2} \mathrm{O}$ synthesized at $200^{\circ} \mathrm{C}$ for $3 \mathrm{~h}$ in $2.5 \mathrm{M} \mathrm{H}_{3} \mathrm{PO}_{4}$ with $\mathrm{P} / \mathrm{Ce}$ atomic ratio of (a) 2.5 by the normal hydrothermal reaction and (b) 5.0 by microwave assisted solvothermal reaction together with those of (c) plate-like $\mathrm{K}_{0.8} \mathrm{Li}_{0.27} \mathrm{Ti}_{1.73} \mathrm{O}_{4}$ and (d) $\mathrm{CeO}_{2}$ nanoparticle. 
by the flux method ${ }^{12}$ and (d) $\mathrm{CeO}_{2}$ nanoparticles prepared by the coprecipitation method ${ }^{4}$ are shown in FIGURE 6. Transparency of visible light region of plate-like $\mathrm{Ce}_{2}\left(\mathrm{PO}_{4}\right)_{2} \mathrm{HPO}_{4} \cdot \mathrm{H}_{2} \mathrm{O}$ and $\mathrm{K}_{0.8} \mathrm{Li}_{0.27} \mathrm{Ti}_{1.73} \mathrm{O}_{4}$ were almost identical and lower than that of $\mathrm{CeO}_{2}$ nanoparticles, probably due to the scattering of light by large particles. As reported in a previous paper, the onset of absorption of $\mathrm{K}_{0.8} \mathrm{Li}_{0.27} \mathrm{Ti}_{1.73} \mathrm{O}_{4}$ was around $350 \mathrm{~nm}$, whereas that of $\mathrm{Ce}_{2}\left(\mathrm{PO}_{4}\right)_{2} \mathrm{HPO}_{4} \cdot \mathrm{H}_{2} \mathrm{O}$ was around $420 \mathrm{~nm}$ which was almost identical to that of ceria. Therefore, the absorption ability of UV-A (320-400 nm) of $\mathrm{Ce}_{2}\left(\mathrm{PO}_{4}\right)_{2} \mathrm{HPO}_{4} \cdot \mathrm{H}_{2} \mathrm{O}$ was higher than that of $\mathrm{K}_{0.8} \mathrm{Li}_{0.27} \mathrm{Ti}_{1.73} \mathrm{O}_{4}$. It is also seen that the UV-absorption ability of $\mathrm{Ce}_{2}\left(\mathrm{PO}_{4}\right)_{2} \mathrm{HPO}_{4} \cdot \mathrm{H}_{2} \mathrm{O}$ prepared by the microwave assisted hydrothermal reaction was lower than that by the normal hydrothermal reaction. It may be due to the difference in the agglomeration state of the particle, i.e., hard agglomeration resulted to decrease the packing density of particles in the film, consequently, degraded the UV-shielding ability.

FIGURE 7 shows the results of the oxidation catalytic activity evaluation by the Rancimat method for $\mathrm{Ce}_{2}\left(\mathrm{PO}_{4}\right)_{2} \mathrm{HPO}_{4} \cdot \mathrm{H}_{2} \mathrm{O}$ and $\mathrm{CeO}_{2}$ nanoparticles. It can be seen that the onset of conductivity increase of $\mathrm{Ce}_{2}\left(\mathrm{PO}_{4}\right)_{2} \mathrm{HPO}_{4} \cdot \mathrm{H}_{2} \mathrm{O}$ was around $10 \mathrm{~h}$ which is much later than that of $\mathrm{CeO}_{2}$ nanoparticles, i.e., $3 \mathrm{~h}$, indicating that the oxidation catalytic activity of $\mathrm{Ce}_{2}\left(\mathrm{PO}_{4}\right)_{2} \mathrm{HPO}_{4} \cdot \mathrm{H}_{2} \mathrm{O}$ was much lower than that of $\mathrm{Ce}_{0.8} \mathrm{Ca}_{0.2} \mathrm{O}_{1.8}$. It is a great advantage when it will be used for cosmetics material.

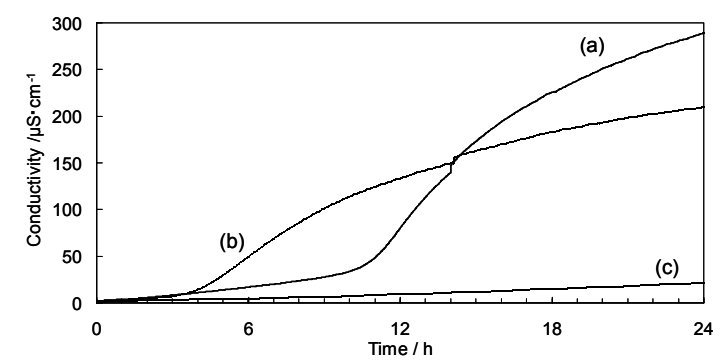

FIGURE 7 Evaluation of the oxidation catalytic activity of (a) $\mathrm{Ce}_{2}\left(\mathrm{PO}_{4}\right)_{2} \mathrm{HPO}_{4} \cdot \mathrm{H}_{2} \mathrm{O}$ by the Ranshimat test together with those of (b) $\mathrm{CeO}_{2}$ nanoparticle and (c) blank test without additive.

In order to evaluate the comfort of applying sample powder to skin, the kinetic friction coefficients of the artificial leather before and after applying various sample powders on were determined using a friction tester. The results are shown in TABLE 1. As expected, plate-like $\mathrm{Ce}_{2}\left(\mathrm{PO}_{4}\right)_{2} \mathrm{HPO}_{4} \cdot$ $\mathrm{H}_{2} \mathrm{O}$ showed similar low kinetic friction coefficient to plate-like $\mathrm{K}_{0.81} \mathrm{Li}_{0.27} \mathrm{Ti}_{1.73} \mathrm{O}_{4}$. The values were higher than that of BN (Mizushima Ferroally Co., SHP-4) which is known as a solid lubricant, but much lower than those of cosmetic grade titania nanoparticles (Ishihara Sangyo Co., TTO-55A) and $\mathrm{Ce}_{0.8} \mathrm{Ca}_{0.2} \mathrm{O}_{1.8}$ nanoparticles. In a previous paper it was reported that by combining with plate-like $\mathrm{K}_{0.81} \mathrm{Li}_{0.27} \mathrm{Ti}_{1.73} \mathrm{O}_{4}$ the kintetic friction coefficient of $\mathrm{Ce}_{0.8} \mathrm{Ca}_{0.2} \mathrm{O}_{1.8}$ nanoparticles could be decreased to almost identical level to that of cosmetic grade talc coated with 50 mass\% tiania (Catalysts \& Chemicals Ind. Co, Coverleaf PC-2055T). Therefore, it may be expected that plate-like $\mathrm{Ce}_{2}\left(\mathrm{PO}_{4}\right)_{2} \mathrm{HPO}_{4} \cdot \mathrm{H}_{2} \mathrm{O}$ is useful as a means to improve the comfort of applying $\mathrm{Ce}_{0.8} \mathrm{Ca}_{0.2} \mathrm{O}_{1.8}$ nanoparticles on the skin.

TABLE 1 Kinetic friction coefficient $(\mu)$ of the various samples.

\begin{tabular}{lcc}
\hline Sample powder & $\mu / \mu_{\mathrm{o}}(\%)$ & S.D. \\
\hline $\mathrm{Ce}_{2}\left(\mathrm{PO}_{4}\right)_{2} \mathrm{HPO}_{4} \cdot \mathrm{H}_{2} \mathrm{O}$ & 63.3 & - \\
$\mathrm{K}_{0.8} 1 \mathrm{Li}_{0.27} \mathrm{Ti}_{1.73} \mathrm{O}_{4}$ & 60.2 & 4.4 \\
$\mathrm{BN}{ }^{* 1}$ & 37.8 & 2.3 \\
$\mathrm{TiO}_{2}{ }^{* 2}$ & 132.1 & 5.9 \\
$\mathrm{Ce}_{0.8} \mathrm{Ca}_{0.2} \mathrm{O}_{1.8}{ }^{* 3}$ & 101.6 & 7.9 \\
${\mathrm{Talc} \mathrm{coated} \mathrm{with} 50 \text { mass } \% \mathrm{TiO}_{2}{ }^{* 4}}^{*}$ & 75.9 & 2.3 \\
$\mathrm{~K}_{0.8} 1 \mathrm{Li}_{0.27} \mathrm{Ti}_{1.73} \mathrm{O}_{4}$ coated with & & \\
50 wt ${ }_{0.8} \mathrm{Ce}_{0.8} \mathrm{Ca}_{0.2} \mathrm{O}_{1.8}{ }^{* 5}$ & 78.5 & 5.7 \\
\hline
\end{tabular}

${ }^{7 T}$ Mizushima Ferroally Co., ${ }^{2}$ Ishihara Sangyo Co., TTO-55A, ${ }^{*}$ Prepared by coprecipitation method ${ }^{4}$, ${ }^{*}$ Catalysts \& Chemicals Ind. Co, Coverleaf PC-2055T, SHP-4, ${ }^{* 5}$ Previous paper ${ }^{8}, \mu_{\mathrm{o}}$ : Artificial leather without sample, $\mu$ : Artificial leather applied the sample powder on.

\section{ACKNOWLEDGMENTS}

This research was partially supported by the Ministry of Education, Culture, Sports, Science and Technology, Scientific Research of Priority Areas "Panoscopic Assembling and High Ordered Functions for Rare Earth Materials", Special Education and Research Expenses on "Post-Silicon Materials and Devices Research Alliance" and the JSPS Asian Core Program "Interdisciplinary Science of Nanomaterials".

\section{REFERENCES}

1. R. Cai, K. Hashimoto, K. Itoh, Y. Kubota and A. Fujita, Bull. Chem. Soc. Jpn., 64, 1268 (1991).

2. T.C. Long, N. Saleh, R.D. Tilton, G.V. Lowry, B.Veronesi, Env. Sci. Technol., 40, 4346 (2006).

3. S. Yabe, S. Momose, J. Soc. Cosmet. Chem. Jpn., 32, 372 (1998).

4. S. Yabe, M. Yamashita, S. Momose, K. Tahira, S. Yoshida, R. Li, S. Yin and T. Sato, Inter. J. Inorg. Mater., 3, 1003 (2001).

5. S. Yabe, M. Yamashita, S. Momose, S. Yoshida, K. Hasegawa, S. Yin and T. Sato, J. Soc. Inorg. Mater. Japan, 8, 428 (2001). 
6. S. Yabe, T. Sato, J. Solid State Chem., 171, 7 (2003).

7. T. Sato, T. Katakura, S. Yin, T. Fujimoto, S. Yabe, Soild State Ionics, 172, 377 (2004).

8. T. Sato, A. M. El-Toni, S. Yin, T. Kumei, J. Ceram. Soc. Japan, 115, 571 (2007).

9. T. Sato, R. Li, C. Sato, S. Yin, Phosphorus Res. Bull., 21, 44 (2007).

10. T. Miyazawa, K. Fujimoto, M. Kinoshita and R. Usuki. J. Am. Oil Chem. Soc., 71, 343 (1994).
11. M. Nazaraly, C. Chaneac, F. Ribot, G. Wallez, M. Quarton, J.P. Jolivet, J. Phys. Chem. Solids, 68, 795 (2007).

12. A. M. El-Toni, S. Yin, T. Sato, Mater. Lett., 60, 185 (2006).

13. V. Brandel, N. Clavier, N. Dacheux, J. Solid State Chem., 178, 1054 (2005). 